\title{
The effects of English versus Persian subtitled movies on Iranian pre-intermediate EFL learners speaking proficiency, willingness to communicate and motivation
}

Zahmatkesh, Mahsa

Department of English, Islamic Azad University, Qaemshahr Branch, Qaemshahr, Iran (mahsa.zahmat.1367@gmail.com)

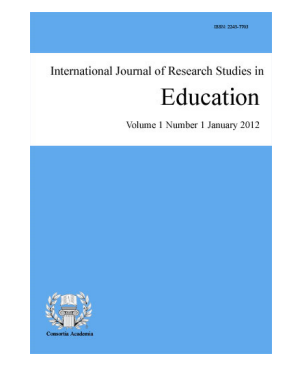

Fakhri Alamdari, Ebrahim $\bowtie$

Department of English, Islamic Azad University, Qaemshahr Branch, Qaemshahr, Iran (ebrahim.fakhri@qaemiau.ac.ir)

ISSN: 2243-7703 Online ISSN: 2243-7711

OPEN ACCESS

Received: 15 May 2021

\section{Abstract}

The present study examined the effects of Persian versus English subtitled movies on the oral proficiency, willingness to communicate (WTC), and motivation of Iranian intermediate EFL learners. The participants were 75 male and female EFL learners from an English language institute in Iran. They were divided into three groups: two experimental: a) English subtitled group $(\mathrm{N}=25)$; Persian subtitled group $(\mathrm{N}=25)$ and a control group (no subtitle, $\mathrm{N}=25)$. The instruments used in this study were: oral proficiency pre- and posttests, WTC pre- and post-questionnaires, and motivation pre- and post-questionnaires. The collected data were analyzed through paired sample t-tests and One-way ANOVAs. The results showed that both Persian and English subtitled films had a significant effect on intermediate EFL learners' oral proficiency. Moreover, there was statistically meaningful difference between the performances of experimental and control groups in oral proficiency after they received the treatment (subtitled films). In addition, both Persian and English subtitled films had a significant on WTC and motivation. This study had a number of implications for language teachers, practitioners and syllabus designers to use subtitled audiovisual programs to facilitate the language learning process for EFL learners.

Keywords: speaking proficiency, subtitled movies, willingness to communicate, motivation 


\section{The effects of English versus Persian subtitled movies on Iranian pre-intermediate EFL learners speaking proficiency, willingness to communicate and motivation}

\section{Introduction}

English, as an international language, has a leading role in every country worldwide. In order to become an adept learner, it is fundamental to master the main four skills: speaking, reading, writing, and listening (Harmer, 2007). From Gan's (2012) point of view, speaking skill refers to the ability to integrate words and make sentences to convey concepts, thoughts and ideas. Speaking skill is also considered as a productive skill in second/foreign language classes and teachers and learners should pay special attention to it (Fachrurrazy, 2012). In foreign language teaching, traditional methods focused on reading and writing skills and generally paid little attention to listening and speaking skills (Raissi, Nor, Aziz, Zainal, \& Saleh, 2013).

One of the most crucial skills in human interaction is speaking. In this global era, millions of people from all over the world use English to communicate more easily with one another (Efrizal, 2012). As Bygate (2009) asserted, language comprehension depends on success in understanding speech. Accordingly, it is required to utilize the modern ways to improve this outstanding and unavoidable skill (Yufrizal, 2018). The rapid growth of access to technological tools in education over the past few decades has provided an opportunity for teachers to use audio-visual materials for language teaching (Fassbender, 2009). In the same vein, Mirvan (2013) maintains that subtitled movies can be regarded as familiar media to contemporary learners, keeping them interested in the theories and concepts under discussion. He also holds the view that the presence of subtitles in English films can play an essential role in understanding, styling and developing speech production.

In addition to being a useful tool for language teaching and learning, the subtitled films, once used to teach a foreign language, can help motivate students and decrease the anxiety of not knowing the language (Siska, 2015). Moreover, they allow teacher to introduce variety and reality into the classroom (Ebrahimi \& Bazaee, 2016). Furthermore, after watching the films, the students can bring their own background knowledge and experience into the classroom through having and maintaining discussions based on the content of the movie (Mirvan, 2013). Various strategies and techniques such as watching movies can play a key role in the development of English language skills, especially the speaking skill. Using subtitles as pedagogical instruments can also play an indispensable role in the process of learning (Araujo \& Costa, 2013). As Koolstra and Beentjes (1999) put it, subtitling means placing a translation or original text based on the target language of the video being displayed on the screen. Furthermore, numerous studies have already demonstrated the impact of utilizing subtitles on improving language comprehension skill as a pedagogical application. Talavan (2010), for instance, conducted a study based on the effect of using subtitles on learners' oral comprehension skill and concluded that subtitled video files could improve speaking skills through text, visual and technology. In addition, subtitled videos could help students view valid input information and generate output content.

Willingness to Communicate (WTC) was also taken into account in the present study. Having and maintaining communication requires interaction on the side of the learners, and in order for interaction to be effective and productive, WTC is indispensable. MacIntyre, Clement, Dornyei, and Noels (1998) define L2 WTC as "a readiness to enter into discourse, at a particular time with a specific person or persons, using L2" (p. 547). Making learners talk is still demanding for teachers, as research has frequently shown that most EFL learners, especially Asians, are passive, quiet, shy, reticent, and unwilling to answer (Liu, Zhang, \& Lu, 2011).

In today's ever-changing world, the need for specialists is greater than ever. English as a universal language is a very important means of communication (Dörnyei \& Ushioda, 2011). Motivation can also be regarded as a crucial factor in the success or failure of any complex activity in language learning. In the same vein, Dörnyei (2009) stated that it could be easy to predict a student's success in L2 learning with the right motivation. Siska 
English VS Persian subtitled on pre-intermediate EFL speaking, willingness to communicate \& motivation

(2015) also asserted that the use of English films could be efficient for learners to increase their motivation. As Richard and Schmidt (2002) defined motivation as a driving force that leads to action, motivation is one of the most momentous constructs in language learning, and a large amount of research on this construct has been conducted in recent decades (Cook, 2000; Csizér, 2017; Dörnyei, 2001, 2005, 2009; Dörnyei, Csizér, \& Németh, 2006; Henry \& Cliffordson, 2013; Lamb, Csizér, Henry, \& Ryan, 2020). Language teachers face crucial problems in ESL/EFL classrooms to create a high level of motivation in students (Ryan \& Deci, 2017).

Given the priorities of this study, focusing on issues such as WTC, it should be noted that the study of this issue is of great importance for foreign language experts for two fundamental reasons. Firstly, according to Peng (2012), learners with a high level of WTC are likely to be highly motivated to seek verbal opportunities in the classroom. Secondly, the mutual understanding of various factors such as personal, social, linguistic and environmental factors related to WTC is of great importance for teachers (Cao, 2011).

Previous research on the use of subtitle has also demonstrated the positive effects of subtitled films versus non-subtitled films. In addition, it was found that the use of subtitles was conducive to vocabulary learning, listening comprehension, speaking ability, and strategies of teaching and translating (Abdolmanafi Rokni \& Jannati Ataee, 2014; Sabouri, Zohrabi, \& Osboui, 2015; Sadiku, 2017; Tabatabaei \& Reisi Gahroei, 2011; Talavan, 2010; Zohdi, 2015). This study, nonetheless, attempted to approach the yet untouched question of whether using English and Persian subtitles could lead to the improvement of Iranian EFL learners' speaking proficiency, WTC and motivation. In addition, there are few studies in the field of comparative effectiveness of subtitled films in the first and target languages on areas such as speaking skills, communication skills, and motivation.

Zohdi (2015) attempted to see the effect of applying movie clips on students' vocabulary knowledge. To this end, the teacher prepared a list of vocabulary of every ten minutes of the movie and presented it to the class during the ten minutes of learners' watching the movie clip and elaborated on the meanings afterwards. The results indicated a significant growth in the learning of new words and expressions. The students were also provided with movie subtitles, leading to their better understanding of the film while watching it. Subtitles could play an effective role in understanding L2 with different accents.

In another study, Sabouri, Zohrabi, and Osboui (2015) investigated the difference between male and female learners in vocabulary learning when watching subtitled movies. To do so, forty-six Iranian upper-intermediate learners participated in the study. The results indicated that regardless of the type and form of subtitled videos, neither gender had a significant advantage over the other one in learning English. Also, the participants in the experimental groups performed better than their counter parts in the control groups in both genders.

Safranj (2014) explored the effect of using movies on fostering listening comprehension. In order to implement this study, the researcher selected thirty-eight students in an English language school in Novi Sad. The researcher evaluated listening abilities through pre- and posttests. A learners' attitudes interview towards applying movies was also conducted to elicit the learners' positive and negative opinions towards the technique. The results demonstrated that using movies proved to be efficient to enhance the learners' listening ability.

Haghverdi and Abdpur (2013) also investigated the possible impact of songs and movies on the language achievement of high school students. To this end, sixty high school male and female students were randomly divided into an experimental group and a control group in an English Language Institute in Iran. The results showed that the use of subtitled films had a significant effect on the development of learners' language in listening, reading and vocabulary.

Latifi, Youhanaee, and Mohammadi (2013) investigated the effect of using movie scripts on improving listening comprehension. To do so, forty-five intermediate students were chosen through an IELTS test. Then, they divided into three main groups: The first group received scripts at home, the second group received class scripts, and a non-scripts group received no scripts. The results demonstrated that there was a significant 
difference among the groups, and the group with scripts had the best performance in listening comprehension.

In another study, Dorshomal, Gorjian, and Pazhakh (2013) investigated the impact of pedagogical films in developing Iranian pre-intermediate students' speaking skill. The study also investigated the effect of educational videos on students' motivation in interactive speaking activities. In order to accomplish the objective of this research, a proficiency test was administered to 120 university students. In the next step, fifty-four pre-intermediate EFL students were selected and then randomly divided into experimental and control groups. To assess their speaking proficiency at the beginning of the treatment period, both groups participated in a pre-test interview and also filled in a motivation questionnaire. The pedagogical films were given to the experimental group and the control group received the audio CDs. After the treatment, both groups were interviewed on the same topics and filled out a questionnaire related to the use of pedagogical films. The results of this study showed that the experimental group outperformed the control group in speaking skill.

In the same line, Bahrani and Soltani (2011) investigated the possible impacts of listening to different TV programs on improving various elements of oral ability. The participants were 20 male and female language learners of English. A sample of speaking from IELTS test was administered as pre-test. During the treatment, various TV programs were presented to the participants. Also, the participants were asked to watch and listen to a television program for four hours at home, summarize everything they watched or listened, and discuss it in class. The results revealed that the participants in the experimental group improved significantly in both the vocabulary knowledge and oral skills during this research.

Given the key role of subtitled films in the language learning process, which has been reported in various studies, researchers still see the gap between whether subtitles in the first language or in the target language can affect the learners' language learning process. To bridge the gap, the current study sought to investigate the effect of English and Persian subtitled films on speaking skill, willingness to communicate, and motivation through the following research questions:

$>$ RQ1: Is there any significant difference between the effects of Persian or English subtitled movies on Iranian pre-intermediate EFL learners' speaking proficiency?

$>$ RQ2: Is there any significant difference between the effects of Persian or English subtitled movies on Iranian pre-intermediate EFL learners' willingness to communicate?

$>$ RQ3: Is there any significant difference between the effects of Persian or English movies on Iranian pre-intermediate EFL learners' motivation?

\section{Methodology}

\subsection{Participants of the Study}

To accomplish the purpose of this study, seventy-five out of eighty-five male and female EFL learners were chosen from four classes at an English language institute in Iran. They were selected based on an Oxford Placement Test (OPT) (Syndicate, 2001). This test is considered as an international test to homogenize language learners' proficiency level. After giving OPT, those who scored one standard deviation (SD) above and below the mean were chosen as the participants. The participants had at least 2 years of experience in language learning. The first language of the participants was Persian, and they were between 13 and 16 years of age.

\subsection{Instruments and Materials}

Oxford Placement Test - The first instrument used in the present study was an Oxford Placement Test (OPT) (Syndicate, 2001). This test is used to homogenize the participants' level of language proficiency. The test involved three main sections as reading, vocabulary and grammar sections. There were sixty questions in two 
English VS Persian subtitled on pre-intermediate EFL speaking, willingness to communicate \& motivation

parts. The first section was related to multiple-choice items and the second part was related to cloze-test. The OPT is regarded as a reliable and effective tool for specifying the current level of learners in language ability.

Speaking Pre- and Post-tests - In order to examine the participants' overall speaking proficiency, the participants completed pre-and post-tests selected from Touchstone 2 (McCarthy, \& Sandiford, 2008) speaking test. The classroom instructor and the instructor's research assistant evaluated the pre-test and post-test audio recordings. It was an unstructured interview as the students were at the low level of English proficiency. The tests took about 8 minutes for each student. Each test consisted of 14 questions. All the participants were tested individually. The items of the tests were based on the inferential questions. Inter-rater reliability of scores given by two raters was done in order to make sure about the reliability of scores given by two raters. Individual performances of students were rated based on Ur's (1996, p.135) oral testing which provided instructors with a scale of oral testing criteria in order to measure the candidates' performance on oral proficiency. According to this scale, learners had the chance to get a maximum of five points on each of these two aspects i.e., ten points in all. Two experienced English teachers revised and commented the items of the tests. The pilot test was done to examine the reliability of the test. The reliability of the speaking pre- and posttests were examined through SPSS version 21. The reliability of the pre- and post-tests was taken care of at the piloting stage through the Cronbach's Alpha formula which turned out to be $($ Pre $=.74$, and Post $=.78)$, respectively. The items of the tests were the same.

WTC Questionnaire - The WTC questionnaire, based on the theory developed by McIntyre, Baker, Clément, and Donovan (2003), was translated into the participants' mother tongue, Persian, in order to avoid any misunderstanding. The questionnaire consisting of 20 items was administered to the students in twenty minutes. They were asked to state how willing they were to initiate and continue a conversation in each situation (from 0 to $100 \%$ ). In order to compare the students' willingness to communicate in Persian and English, the questionnaire was designed to assess WTC in the Persian language. After gathering the data, they were analyzed and the $\alpha$ Cronbach reliability was computed. This questionnaire enjoyed a reliability coefficient of .92 .

The Motivation Questionnaire - Another instrument was a motivation questionnaire, constructed by Dornyei (2010). This questionnaire had three sections with 33 items. It was also translated into Persian. In the first section of the questionnaire, there were 26 statements associated with the participants' attitudes towards language learning and their goals in language learning. The second section of this questionnaire consisted of 7 statements based on participants' attitudes towards skills in language learning. The third section of this questionnaire was related to the personal information of participants such as their gender, age, nationality, year of study, major, overseas experience, English teacher, and their English ability. The reliability coefficient of this questionnaire was .87 , which was acceptable. This questionnaire was valid as it had been used several times in the Iranian context by Shahab (2013).

Touchstone Textbook - Touchstone $2^{\text {nd }}$ Edition is regarded as an interactive textbook series for language learners, especially young adults and adults. In this study, the teacher selected four chapters from the students' book of Touchstone 2 (McCarthy, McCarten, \& Sandiford, 2008). This textbook is used for pre-intermediate learners.

Subtitled Films - The teacher selected four English films from the learners' textbook (Video book of Touchstone 2) (McCarthy, McCarten, \& Sandiford, 2008). They were in three formats: English subtitles, Persian subtitles, and no subtitles. The topics of these films were food, locations, regions, and countries. The movies were selected based on the content and the level of difficulty for the participants.

\subsection{Data Collection Procedure}

The procedure was carried out in eleven sessions. To assure the homogeneity of the participants, they were asked to take the OPT. After administering OPT, seventy-five out of eighty-five pre-intermediate learners were selected at an English language institute in Iran. The participants were divided into three groups: two 
experimental groups: 1) In the first experimental group, the learners received English subtitled films $(\mathrm{N}=25), 2)$ The second experimental group received Persian subtitled films $(\mathrm{N}=25)$, and the third group was a control group $(\mathrm{N}=25)$, receiving non-subtitled films. All participants took the oral proficiency pre-test, WTC pre-questionnaire, and motivation pre-questionnaire.

Each session of the class was about 75 minutes, held twice a week. The researcher selected four films from the video book of Touchstone 2 (McCarthy, McCarten, \& Sandiford, 2008). The topics of these films were food, locations, regions, and countries. After teaching each lesson (dialogs, reading text, and speaking section), the teacher showed the film to each group in 25 minutes. For the first experimental group, the films had English subtitles. For the second experimental group, the films had Persian subtitles, and for the control group; the films did not have any subtitles. At the end of showing each movie, the teacher asked a number of questions and had a discussion about the main idea, the peak of the story, and the summary of video clips. After finishing the films, the learners attempted to write a summary in five minutes and the teacher attempted to help learners when they had problems in writing a summary. Next, the learners had to read their summaries in front of other classmates. After giving instructions, all groups took the speaking proficiency posttest, WTC post-questionnaire and motivation post-questionnaire.

\subsection{Design and Data Analysis}

This study was a cause-and-effect study. This study was based on a quantitative study (quasi-experimental method). It followed a model as the pre-test, treatment and the post-test design. The data were analyzed through a SPSS package version 22. Firstly, the descriptive statistics were calculated and then the inferential statistics were analyzed through. There were three questions in the present study. To see the significant difference between Persian and English subtitled movies on Iranian pre-intermediate EFL learners' speaking proficiency, one-way ANOVA was applied. To analyze the significant difference between Persian and English subtitled movies on Iranian pre-intermediate EFL learners' willingness to communicate, one-way ANOVA was applied. To see the significant difference between Persian and English subtitled movies on Iranian pre-intermediate EFL learners' motivation, one-way ANOVA was also applied.

\section{Results}

\subsection{The Analysis of the First Research Question}

The first research question attempted to examine "whether there is any statistically significant difference between Persian subtitled movies and English subtitled movies regarding their effectiveness on speaking proficiency or not". The descriptive statistics of speaking pre- and post-scores of the three groups (The Persian subtitle, the English subtitle, and the control groups) are presented in Table 1.

\section{Table 1}

Descriptive Statistics of Speaking Pre and Post-tests

\begin{tabular}{lrrrcc}
\hline Groups & N & Mean & SD & Min. & Max. \\
\hline Ex1-pre & 25 & 13.80 & 1.57 & 12 & 16 \\
Ex2-pre & 25 & 13.50 & 1.61 & 11 & 15 \\
CG- pre & 25 & 13.35 & 1.64 & 11 & 15 \\
\hline Ex1post & 25 & 16.90 & 1.89 & 13 & 18 \\
Ex2post & 25 & 15.90 & 1.78 & 13 & 17 \\
CG post & 25 & 14.35 & 1.70 & 13 & 15 \\
\hline
\end{tabular}

As shown in Table 1, the three groups had the following means and standard deviations: The Persian subtitled group $(X=13.80, S D=1.57)$; The English subtitled group $(X=13.50 ; S D=1.61)$, and the control group $(X=13.35 ; S D=1.64)$. As it can be seen, the means of the speaking pre-scores of the three groups are 
English VS Persian subtitled on pre-intermediate EFL speaking, willingness to communicate \& motivation

different. Accordingly, a One-way ANOVA was used to compare the means of the three groups. The analysis (Table 2) revealed that there was no significant difference $(p=.173>.05)$ between the performance of The Persian subtitle, the English subtitle and the control groups in speaking proficiency before the treatment. Table 2 shows the descriptive statistics of speaking proficiency posttest scores.

Table 2

One-way ANOVA results comparing the three groups in pre and post-tests of speaking

\begin{tabular}{lccccc}
\hline Pre vs. Post-tests & Sum of Squares & df & Mean Square & F & Sig \\
\hline Between Groups & 3.32 & 2 & 1.87 & .522 & .173 \\
Within Groups & 182.84 & 72 & 3.21 & & \\
Total & 186.16 & 74 & & & \\
\hline Between Groups & 2.23 & 2 & 1.31 & .791 & .002 \\
Within Groups & 160.50 & 72 & 2.99 & & \\
Total & 162.73 & 74 & & & \\
The Effect Size & 0.01 & & & & \\
\hline
\end{tabular}

As shown in Table 1, the descriptive statistics of the three groups are as follows: The Persian subtitle group $(X$ $=16.90, S D=1.89)$; the English subtitle group $(X=15.90 ; S D=1.78)$, and the control group $(X=14.00 ; S D=$ 1.70). As it can be seen, the mean of the three groups in the post-test is different. Accordingly, One-way ANOVA was used to compare the means of the three groups. The analysis (Table 2) revealed that there was a significant difference $(p=.002<.05)$ between the performances of Persian subtitle, English subtitle and the control groups in oral performance after the treatment. For observing the differences between groups in post-test scores, Tukey HSD was run as presented by Table 3 .

\section{Table 3}

Multiple comparisons for the post-tests of speaking

\begin{tabular}{lccc}
\hline Tests & Mean & SE & Sig. \\
\hline Ex1 vs. Ex2 & 1.00 & .20 & .004 \\
Ex1 vs. CG & 2.90 & .20 & .000 \\
Ex2 vs. CG & 1.90 & .20 & .000 \\
\hline
\end{tabular}

Table 3 showed the differences between the three groups. In this regard, there was a significant difference between Persian subtitle, English subtitle, and the control groups in oral performance. The results showed that the Persian subtitle group significantly outperformed the control group. In addition, there was a significant difference between the English subtitle group and the control group. In other words, the English subtitle group outperformed the control group. There was a significant difference between the Persian subtitle group and the English subtitled group as well.

\subsection{The Analysis of the Second Research Question}

To answer the second research question of this study stating, "whether there is any statistically significant difference between Persian subtitled movies and English subtitled movies regarding their effectiveness on willingness to communicate or not", the descriptive statistics of willingness to communicate pre- and post-scores of three groups (The Persian subtitle, the English subtitle, and the control groups) are presented in Table 4.

As indicated in Table 4, the three groups had the following means and standard deviations: The Persian subtitled group ( $X=55, S D=3.02)$; the English subtitled group $(X=55 ; S D=2.98)$, and the control group $(X=$ $50 ; S D=2.80$ ). As it can be seen, the means of the WTC pre-scores of the three groups are different. Accordingly, One-way ANOVA was used to compare the means of the three groups. The analysis (Table 5) indicated that there was no significant difference $(p=.179>.05)$ between the performances of the Persian subtitle, the English subtitle, and the control groups in willingness to communicate before the treatment. Table 5 shows the descriptive statistics of willingness to communicate posttest scores. 
Zahmatkesh, M., \& Fakhri Alamdari, E.

\section{Table 4}

Descriptive Statistics of WTC Pre and Post-test Scores

\begin{tabular}{lccccc}
\hline Groups & $\mathrm{N}$ & Mean & SD & Min. & Max. \\
\hline Ex1-pre & 25 & 55 & 3.02 & 40 & 60 \\
Ex2-pre & 25 & 55 & 2.98 & 40 & 60 \\
CG- pre & 25 & 50 & 2.80 & 30 & 60 \\
\hline Ex1post & 25 & 70 & 3.18 & 40 & 80 \\
Ex2post & 25 & 60 & 3.02 & 40 & 80 \\
CG post & 25 & 50 & 2.97 & 30 & 70 \\
\hline
\end{tabular}

Table 5

One-way ANOVA results comparing the three groups in pre and post-tests of WTC

\begin{tabular}{lccccc}
\hline Pre vs. Post-tests & Sum of Squares & df & Mean Square & F & Sig \\
\hline Between Groups & 5.01 & 2 & 1.98 & .567 & .179 \\
Within Groups & 243.60 & 72 & 3.84 & & \\
Total & 248.61 & 74 & & & \\
\hline Between Groups & 6.13 & 2 & 1.99 & .612 & .003 \\
Within Groups & 251.50 & 72 & 3.99 & & \\
Total & 256.63 & 74 & & & \\
The Effect Size & 0.02 & & & & \\
\hline
\end{tabular}

As revealed by Table 4, the descriptive statistics of the three groups: The Persian subtitle group $(X=70, S D=$ $3.18)$; the English subtitle group $(X=60 ; S D=3.02)$, and the control group $(X=50 ; S D=2.97)$. As it can be seen, the means of the three groups in the WTC post-questionnaire are different. Accordingly, One-way ANOVA was used to compare the means of the three groups. The analysis (Table 5) revealed that there was a significant difference $(p=.003<.05)$ between the performances of Persian subtitle, English subtitle, and the control groups in WTC performance after the treatment. For observing the differences between the groups in WTC post-questionnaire scores, Tukey HSD was run as presented by Table 6 .

Table 6

Multiple comparisons for the post-tests of WTC

\begin{tabular}{lccc}
\hline Tests & Mean & SE & Sig. \\
\hline Ex1 vs. Ex2 & 10.00 & .22 & .003 \\
Ex1 vs, CG & 20.00 & .22 & .000 \\
Ex2 vs. CG & 10.00 & .22 & .000 \\
\hline
\end{tabular}

Table 6 showed the differences between the three groups. In this regard, there was a significant difference between Persian subtitle, English subtitle, and the control groups in WTC. The results showed that the Persian subtitle group significantly outperformed the control group. In addition, there was a significant difference between the English subtitle group and the control group. In other words, the English subtitle group outperformed the control group. There was a significant difference between the Persian subtitle group and the English subtitled group, and it was also found that the Persian subtitled group significantly outperformed the English subtitled group.

\subsection{The Analysis of the Third Research Question}

The third research question of this study strove to examine, "whether there is any statistically significant difference between Persian subtitled movies and English subtitled movies regarding their effectiveness on motivation or not". The descriptive statistics of motivation pre- and post-scores of three groups (The Persian subtitle, the English subtitle, and the control groups) are presented in Table 7. 
English VS Persian subtitled on pre-intermediate EFL speaking, willingness to communicate \& motivation

Table 7

Descriptive Statistics of Motivation Pre and Post-test Scores

\begin{tabular}{lccccc}
\hline Groups & N & Mean & SD & Min. & Max. \\
\hline Ex1-pre & 25 & 98 & 7.09 & 85 & 110 \\
Ex2-pre & 25 & 93 & 6.80 & 81 & 105 \\
CG- pre & 25 & 94 & 6.93 & 80 & 108 \\
\hline Ex1post & 25 & 121 & 8.07 & 110 & 132 \\
Ex2post & 25 & 106 & 7.36 & 98 & 114 \\
CG post & 25 & 99 & 7.01 & 89 & 108 \\
\hline
\end{tabular}

Table 8

One-way ANOVA results comparing the three groups in pre and post-tests of motivation

\begin{tabular}{lccccc}
\hline Pre vs. Post-tests & Sum of Squares & df & Mean Square & F & Sig \\
\hline Between Groups & 7.25 & 2 & 2.32 & .603 & .191 \\
Within Groups & 389.60 & 72 & 5.90 & & \\
Total & 396.85 & 74 & & & \\
\hline Between Groups & 8.39 & 2 & 2.83 & .736 & .021 \\
Within Groups & 452.37 & 72 & 7.40 & & \\
Total & 460.76 & 74 & & & \\
The Effect Size & 0.01 & & & & \\
\hline
\end{tabular}

As shown in Table 7, the three groups had the following means and standard deviations: The Persian subtitled group $(X=97.5, S D=7.09)$; The English subtitled group $(X=93 ; S D=6.80)$, and the control group ( $X$ $=94 ; S D=6.93)$. As it can be seen, the means of the motivation pre-scores of the three groups are different. Accordingly, One-way ANOVA was used to compare the means of the three groups. The analysis (Table 8) revealed that there was no significant difference $(p=.191>.05)$ between the performances of the Persian subtitle, the English subtitle, and the control groups in motivation before the treatment. Table 8 shows the descriptive statistics of motivation posttest scores.

As revealed by Table 7, the descriptive statistics of the three groups: The Persian subtitle group $(X=121, S D$ $=8.07)$; the English subtitle group $(X=106 ; S D=7.36)$, and the control group $(X=98.5 ; S D=7.01)$. As it can be seen, the means of the three groups in the motivation post-questionnaire are different. Accordingly, One-way ANOVA was used to compare the means of the three groups. The analysis (Table 8) indicated that there was a significant difference $(p=.021<.05)$ between the performances of Persian subtitle, English subtitle, and the control groups in motivation performance after the treatment. For observing the differences between the three groups in motivation post-questionnaire scores, Tukey HSD was run as presented by Table 9.

Table 9

Multiple comparisons for the post-tests of motivation

\begin{tabular}{lccc}
\hline Tests & Mean & SE & Sig. \\
\hline Ex1 vs. Ex2 & 15.00 & .19 & .001 \\
Ex1 vs, CG & 22.50 & .19 & .000 \\
Ex2 vs. CG & 7.50 & .19 & .004 \\
\hline
\end{tabular}

Table 9 showed the differences between the three groups. In this regard, there was a significant difference between Persian subtitle, English subtitle, and the control groups in motivation. Based on the results, it was found that the performance of the Persian subtitled group was significantly better than that of the control group. In addition, there was a significant difference between the English subtitle group and the control group. In other words, the English subtitle group outperformed the control group. There was also a significant difference between the Persian subtitle group and the English subtitle group. As a matter of fact, the Persian subtitled group significantly outperformed the English subtitle group. 


\section{Discussion}

This study attempted to compare the impact of Persian versus English subtitled movies on speaking proficiency, WTC, and motivation of Iranian pre-intermediate EFL learners. The results revealed that learners who had watched both Persian and English subtitled movies significantly outperformed their peers in the control group in oral proficiency.

The findings of the current study are congruent with the result of a study by Dunchi and Dikilitas (2009), revealing two important conclusions. One of the most important results was that movies can play a very effective role in increasing speech skills. Another key result of this study is the important role of subtitled films in increasing motivation. This is because students can better understand the content of subtitled videos. The findings of this study are also in line with the results of the research conducted by Bahrani and Soltani (2011). They found that films improved oral proficiency of the learners. In addition, their study revealed that vocabulary and communication components of speaking were enhanced more than the other components. The results of this study are, nevertheless, not in line with the findings of a study by Mekheimer (2011).

In addition, the results of this study are consistent with the findings of a study by Ardriyati (2010), demonstrating that the use of films in teaching could motivate language learners. According to him (2010) films can make students become more motivated to speak and communicate in the language. The findings of a study by Istanto (2009) is not, however, consistent with the results of the current study. According to Istanto, films cannot provide strong motivation for learners to speak the target language because they can learn in more interesting ways compared to traditional class activities. The results of the current study are also congruous with those of a study by Jahangard (2007), discovering that visual materials can increase language learning in the classroom. In addition, the results are consistent with the findings of Ardriyati (2010), stating that communication plays an essential role when teachers use films in the classroom as a teaching material.

In some other studies such as those conducted by Beauprez (2014) and Raine (2012), the positive impact of subtitled films on L2 vocabulary knowledge of EFL students have been confirmed. In addition, Raine (2012) found that subtitled films are effective means for both L2 speaking ability and listening comprehension. The results of the present study support those of the previous studies because they also confirm the effectiveness of subtitled films. Indeed, subtitles have had a positive effect on learners' accuracy and fluency as two components of speaking. Of course, according to Yurong and Nan (2008), other factors such as motivation, anxiety and self-esteem are involved in increasing fluency in L2.

This study also investigated the significant effect of Persian versus English subtitled movies on the WTC of Iranian pre-intermediate EFL learners. The results revealed that learners who had watched Persian subtitled movies in classrooms had significant improvements in WTC, and that their scores increased significantly.

The results of the present study are consistent with Grignon, Lavaur, and Blanc (2005), that compared three versions of a film sequence (dubbed, subtitled, and original versions). They found that the dubbed and subtitled versions led to better performance than the original version, and the finding of the present study indicated that there was a significant difference among the means of participants in the Persian subtitle, English subtitle and no subtitle groups in communicating with others. WTC is not a simple display of linguistic competence or communicative competence; however, it is an interplay of communicative, linguistic, and socio-psychological factors. As shown by Matsuoka and Evans (2005), Yashima and Zenuk-Nishide (2008) Alemi, Daftarifard and Pashmforoosh (2011), learners with high comprehension are more willing to communicate in L2.

This study also investigated the significant effect of Persian versus English subtitled movies on the motivation of Iranian pre-intermediate EFL learners. The results also indicated that learners who had watched Persian subtitled movies in classrooms had significant improvements in motivation, and that their scores increased significantly. The results of the present study with regard to motivation are also consistent with those of the previous studies (Haghverdi \& Abdpur, 2013; Khosravi, Rezaee, Ahmadi, \& Aghajanzade, 2015). 


\section{Conclusion and Implications}

There is no doubt that movies can be regarded as effective and versatile teaching materials, especially in societies where the number of TV lovers and computer users are expanding with great haste. As video technology changes at a greater speed, our options are advancing, too, and they are not limited to traditional video cassettes only. Although they still seem to be the most accessible resources in many schools, they are out-of-date nowadays, and learners do not willingly accept them.

It is inevitable, of course, that more advanced technological tools such as interactive video CD, DVD and web-based multimedia tools have become increasingly more popular aids in the EFL classrooms. The integration of old and new technologies seems very attractive, which requires more research and studies in this area of expertise. In the meantime, research conducted with subtitled movies can contribute to our understanding of more advanced video and multimedia technology, and how it can best be used for teaching in an EFL classroom.

One outstanding result of this study was the key role of Persian subtitles in movies, which was more effective than English subtitles in increasing speech ability, motivation and desire to communicate. This meant that students could communicate better through their first language (L1) rather than their L2 in order to understand the content of the film.

This study has yielded a number of investigations about the use of movies with subtitles, confirming previous research indicating that movies are beneficial and effective because they result in greater focus and exposure to foreign language. It can also improve overall attention and reinforce the acquisition of speaking ability. In the same vein, the results of this study revealed that movies, may reduce learners' anxiety, improve their global listening strategies, and promote the understanding of the words in the context.

Turning to educational implications, it should be noted that although this study emphasized the fact that subtitled videos can facilitate various aspects of learning such as speaking skills, motivation and WTC, they are not essential components in the classroom. It greatly depends on how pedagogically appropriate films are used and how effectively they are used in teaching. Films and their special features such as subtitles were of a great help to develop an effective learning environment. Teachers can employ movie-based instruction to improve students' four main skills and also the ability of improving vocabulary and grammar. Material designers are advised to acquaint EFL learners with the substance and advantages of using pedagogical films in language classrooms so that language learners with different language abilities may draw upon them. These conclusions are of immense significance for all those individuals who work as educational planners, teachers, parents and learners in educational contexts.

\section{References}

Abdolmanafi Rokni, S. J., \& Jannati Ataee, A. (2014). The effects of movie subtitles on EFL learners' oral performance. International Journal of English Language Literature and Humanities, 1(5), 201-215.

Alemi, M., Daftarifard, P., \& Pashmforoosh, R. (2011). The impact of language anxiety and language proficiency on WTC in EFL context. Cross-Cultural Communication, 7(3), 150-166.

Araújo, L., \& da Costa, P. D. (2013). The European survey on language competences: School-internal and external factors in language learning. EUR-OP.

Ardriyati, W. (2010). Using an authentic and selected film for teaching listening and speaking. Jurnal Ilmiah Dinamika Bahasa dan Budaya, 4(2), 54-65.

Bahrani, T., \& Soltani, R. (2011). The pedagogical values of cartoons. Research on Humanities and Social Sciences, 1(4), 19-21.

Beauprez, C. (2014). The influence of subtitles on the vocabulary acquisition of Flemish students prior to the instruction of English. Masters' Thesis. University of Kentucky, College of Agriculture, Gent, Belgium.

Bygate, M. (2009). Teaching the spoken foreign language. In K. Knapp and B. Seidlhofer (eds.), Foreign 
Language and Communication (pp. 401-438). Mouton de Gruyter.

Cao, Y. (2011). Investigating situational willingness to communicate within second language classrooms from an ecological perspective. System, 39 (4), 468-479. https://doi.org/10.1016/j.system.2011.10.016

Cook, V. (2000). Linguistics and second language acquisition. Foreign Language Teaching and Research Press and Macmillan Publishers Ltd.

Csizer, K. (2017). The internal structure of language learning motivation: Results of structural equation modeling. Modern Language Journal, 89(1), 19-36. https://doi.org/10.1111/j.0026-7902.2005.00263.x

Dikilitas, K., \& Duvenci, A. (2009). Movies in teaching oral skill. Social and Behavioral Sciences, 5(1), 190-205.

Dornyei, Z. \& Ushioda, E. (2011). Teaching and researching motivation. Pearson, Harlow.

Dornyei, Z. (2001). Motivation in action: Towards a process-oriented conceptualization of student motivation. British Journal of Educational Psychology, 70, 519-538.

Dornyei, Z. (2005). The psychology of the language learner: Individual differences in second language acquisition. Lawrence Erlbaum.

Dornyei, Z. (2009). The psychology of second language acquisition. Oxford University Press.

Dornyei, Z. (2010). Questionnaires in second language research: Construction, administration, and processing. Routledge.

Dörnyei, Z., Csizér, K., \& Németh, N. (2006). Motivation, language attitudes, and globalization: A Hungarian perspective. Multilingual Matters.

Dorshomal, N., Gorjian, B., \& Pazhakh, A. (2013). The role of pedagogical films in developing Iranian pre-intermediate EFL Learners' speaking skill: The case of motivation. International Journal of Language Learning and Applied Linguistics World, 4(4), 254-268.

Ebrahimi, Y., \& Bazaee, P. (2016). The effect of watching English movies with standard subtitles on EFL learners' content and vocabulary comprehension. Journal of Applied Linguistics and Language Research, 3(5), 284-295.

Efrizal, D. (2012). Improving students' speaking through communicative language teaching method at Mts Ja-alhaq, Sentot Ali Basa Islamic boarding school of Bengkulu, Indonesia. International Journal of Humanities and Social Science, 2(20), 127-134.

Fachrurrazy, D. (2012). Teaching English as a foreign language for teachers in Indonesia. State University of Malang Press.

Fassbender, E. (2009). Effects of showing movies in a speaking class in the context of Bangladesh. Language Teaching Research in Malaysia, 3(2), 120-131.

Gan, Z. (2012). Understanding L2 speaking problems: Implications for ESL curriculum development in a teacher training institution in Hong Kong. Australian Journal of Teacher Education, 37(1), 43-59.

Grignon, P. M., Lavaur, J., \& Blanc, N. (2005). The effect of subtitles on film understanding. http://www.google.com/search?hl=en+q=the+effect+of+subtitles+on+film+understnding+b+nG=google + search

Haghverdi, H. R., \& Abdpur, S. (2013). The effect of songs and movies on high school students' language achievement. Journal of Language, Culture, and Translation (LCT), 2(1), 27-38.

Harmer, J. (2007). The practice of English language teaching. Longman.

Henry, A., \& Cliffordson, C. (2013). Motivation, gender, and possible selves. Language learning, 63(2), 271-295.

Istanto, J. W. (2009). The use of film as an innovative way to enhance language learning and cultural understanding. Electronic Journal of Foreign Language Teaching, 6(1), 278-290.

Jahangard, A. (2007). Evaluation of the EFL materials taught at Iranian high schools. The Asian EFL Journal Quarterly, 9(2), 130-150.

Koolstra, C. M., \& Beentjes, J. W. (1999). Children's vocabulary acquisition in a foreign language through watching subtitled television programs at home. Educational Technology Research and Development, 47(1), 51-60.

Lamb, M., Csizér, K., Henry, A., \& Ryan, S. (2020). Palgrave Macmillan handbook of motivation for language learning. Palgrave.

124 Consortia Academia Publishing (A partner of Network of Professional Researchers and Educators) 
English VS Persian subtitled on pre-intermediate EFL speaking, willingness to communicate \& motivation

Latifi, M., Youhanaee, M., \& Mohammadi, E. (2013). Simplifying the text or simplifying the task: How to improve listening comprehension. Porta Linguarum: revista internacional de didáctica de las lenguas extranjeras, (19), 7-22.

Liu, M., Zhang, W., \& Lu, Z. (2011). Reticence and anxiety in Chinese university ESP poetry class: A case study. Journal of Languages and Culture, 2(2), 20-33.

MacIntyre, P. D., Baker, S. C., Clément, R., \& Donovan, L. A. (2003). Talking in order to learn: Willingness to communicate and intensive language programs. Canadian Modern Language Review, 59(4), 589-607.

MacIntyre, P. D., Clément, R., Dörnyei, Z., \& Noels, K. A. (1998). Conceptualizing willingness to communicate in a L2: A situational model of L2 confidence and affiliation. The Modern Language Journal, 82(4), 545-562.

McCarthy, M., McCarten, J., \& Sandiford, H. (2008). Touchstone textbook. Cambridge University Press.

Mekheimer, M. A. (2011). The impact of using videos on whole language learning in EFL context. Arab World English Journal, 2(2), 5-39.

Mirvan. X. (2013). The advantages of using films to enhance student's reading skills in the EFL classroom. Journal of Education and Practice, 13(4), 62-67.

Peng, J. (2012). Towards an ecological understanding of willingness to communicate in EFL classrooms in China. System, 40(2), 203-213.

Raine, P. (2012). Incidental learning of vocabulary through subtitled authentic videos. Masters' Thesis. University of Birmingham, Birmingham, United Kingdom.

Raissi, R., Nor, F. M., Aziz, M. A., Saleh, Z. M., \& Zainal, Z. (2013). Student's understandings and practices regarding communicative language teaching (CLT) in Malaysian secondary schools. Mediterranean Journal of Social Sciences, 4(4), 325-325.

Richards, J. C., \& Schmidt, R. (2002). Longman dictionary of language teaching \& Applied Linguistics ( $3^{\text {rd }}$ ed.). Pearson Education Limited.

Ryan, R. M., \& Deci, E. L. (2017). Self-determination theory: Basic psychological needs in motivation, development, and wellness. Guilford Publications.

Sabouri, H. \& Zohrabi, M. (2015). The impact of watching English subtitled movies in vocabulary learning in different genders of Iranian EFL learners. International Journal on Studies in English Language and Literature, 3(2), 110-125.

Sadiku, A. (2017). The impact of subtitled movies on vocabulary development. International Journal of Business and Technology, 6(1), 45-57.

Safranj, J. (2015). Advancing listening comprehension through movies. Procedia-Social and Behavioral Sciences, 191, 169-173.

Siska, S. (2015). Using film to increase motivation for speaking in English course classroom. TELL-US Journal, $1(2), 51-57$.

Syndicate, U. C. L. E. (2001). Quick placement test. Oxford University Press.

Tabatabaei, O., \& Gahroei, F. R. (2011). The Contribution of Movie Clips to Idiom Learning Improvement of Iranian EFL Learners. Theory \& Practice in Language Studies, 1(8).

Talavan, N. (2007). Using subtitles in a multimedia environment to enhance listening comprehension for foreign language students of English. In Proceedings VI International AELFE Conference. Lisboa: ISCAL (pp. 452-458).

Yufrizal, H. (2018). The application of 4/3/2 technique to enhance speaking fluency of EFL students in Indonesia. Advances in Social Sciences Research Journal, 5(10), 99-107.

Yurong, Zh., \& Nan, Y. (2008). The effects of affective factors on oral English fluency of college English students. Celea Journal, 31(2), 107-116.

Zohdi, S. (2015). Supporting listening comprehension and vocabulary acquisition with multimedia annotations: The students' voice. CALICO Journal, 21(1), 41-65. 
Zahmatkesh, M., \& Fakhri Alamdari, E.

126 Consortia Academia Publishing (A partner of Network of Professional Researchers and Educators) 